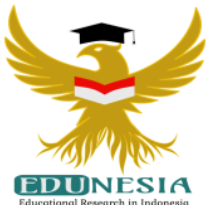

\title{
Pendidikan Karakter Pada Mata Kuliah Pancasila STKIP PGRI Lubuklinggau
}

\author{
Andriana Sofiarini \\ Pendidikan Sejarah, STKIP PGRI Lubuklinggau, Indonesia \\ Corresponding Email: andriesophie205@gmail.com, Phone Number :0856 xxxx xxxx
}

\section{Article History:}

Received: Dec 03, 2020

Revised: Dec 10, 2020

Accepted: Dec 15, 2020

Published: Jan 01, 2021

\section{Keywords:}

Character, Local

Wisdom, Pancasila,

STKIP PGRI

Lubuklinggau

Kata Kunci:

Karakter, Kearifan

Lokal, Pancasila, STKIP

PGRI Lubuklinggau

How to cite:

Sofiarini, A. (2021)

Pendidikan Karakter Pada

Mata Kuliah Pancasila

STKIP PGRI Lubuklinggau.

Edunesia: Jurnal Ilmiah

Pendidikan, 2 (1): 230-239.

This is an open access article under the CC-BY-NC-ND
Abstract: The purpose of this study was to determine the character education in the Pancasila subject for STKIP PGRI Lubuklinggau Students. How is character education integrated in the learning process contained in the values of Pancasila. Its application for the world of education in higher education is through Lecturers who teach the Pancasila course. The research method used is a qualitative description method. The instrument used in this study was direct observation in the field. Researchers in this qualitative research are lecturers in the Pancasila subject at STKIP PGRI Lubuklinggau. Results and discussion, namely: 1) Character and Local Wisdom is a character as an Indonesian human being built through ethical values that come from local wisdom on elements of religion, state philosophy, and culture. Becoming a multicultural nation is a gift and continues to be an Indonesian man with noble character and character, 2) Character Education in the Pancasila Course for STKIP PGRI Lubuklinggau Students, namely the campus as an educational institution is a place to develop themselves and also form good character. Through the Pancasila course, character education can be applied from this.It should also be explained that the Pancasila course must be taken as the essence of strengthening the character and local wisdom of the nation. The implementation of character education in Pancasila courses must also be applied in campus activities as well as in positive activities in the general public. Lecturers who teach Pancasila courses must be really able to practice the values contained in every material they teach. The application of character education will later leave an impression on students to become students who are smart, have broad insight, and have a love for the country and the nation.

Abstrak: Tujuan penelitian ini adalah untuk mengetahui pendidikan karakter pada mata kuliah Pancasila Mahasiswa STKIP PGRI Lubuklinggau. Bagaimana pendidikan karakter yang menyatu dalam proses pembelajaran yang terkandung didalam nilai-nilai Pancasila. Penerapanya bagi dunia pendidikan di perguruan tinggi melalui Dosen pengampu mata kuliah Pancasila. Metode penelitian yang digunakan adalah metode deskripsi kualitatif. Instrument yang digunakan dalam penelitian ini berupa pengamatan secara langsung dilapangan. Peneliti dalam penelitian kualitatif ini adalah sebagai Dosen pengampu mata kuliah Pancasila di STKIP PGRI Lubuklinggau. Hasil dan pembahasan, yaitu: 1) Karakter dan Kearifan Lokal adalah Karakter sebagai manusia Indonesia dibangun melalui nilai-nilai etika yang bersumber dari kearifan lokal atas unsur agama, filsafat negara, dan budaya. Menjadi sebuah bangsa yang multikulutural adalah sebuah anugerah dan tetap menjadi manusia Indonesia yang berkarakter dan berbudi pekerti yang luhur, 2) Pendidikan Karakter Pada Mata Kuliah Pancasila Mahasiswa STKIP PGRI Lubuklinggau, yaitu Kampus sebagai lembaga pendidikan merupakan tempat mengembangkan diri dan juga membentuk karakter yang baik. Melalui mata kuliah Pancasila, pendidikan karakter dapat diterapkan dari hal tersebut. Perlu juga dijelaskan bahwa mata kuliah Pancasila harus diambil inti sarinya sebagai penguatan karakter dan kearifan lokal bangsa. Penerapan pendidikan karakter mata kuliah Pancasila juga harus diaplikasikan dalam kegiatan-kegiatan kampus maupun kegiatan yang positif di lingkungan masyarakat umum. Dosen pengampu mata kuliah Pancasila harus benar-benar mampu mengamalkan nilai-nilai yang terkandung dalam setiap materi yang diajarkannya. Penerapan pendidikan karakter nantinya akan membekas dalam diri mahasiswa untuk menjadi mahasiswa yang cerdas, berwawasan luas, dan memiliki rasa cinta tanah air dan bangsa. 


\section{A. Pendahuluan}

Era globalisasi saat ini, penting sekali dalam menjaga kaidah pendidikan karakter yang menjadi ciri khas bangsa Indonesia. Gerenasi muda yang baik akan tumbuh dengan baik jika memiliki karakter yang mumpuni. Untuk memenuhi sumberdaya manusia tersebut, pendidikan memiliki peran yang sangat penting. Hal ini sesuai dengan UU No 20 Tahun 2003 Tentang Sistem Pendidikan Nasional pada Pasal 3, yang menyebutkan bahwa pendidikan nasional berfungsi mengembangkan kemampuan dan membentuk karakter serta peradaban bangsa yang bermartabat dalam rangka mencerdaskan kehidupan bangsa. Pendidikan nasional bertujuan untuk berkembangnya potensi peserta didik agar menjadi manusia yang beriman dan bertakwa kepada Tuhan Yang Maha Esa, berakhlak mulia, sehat, berilmu, cakap, kreatif, mandiri, dan menjadi warga negara yang demokratis serta bertanggung jawab.

Menurut (Kemdiknas, 2003), Pendidikan adalah usaha sadar dan terencana untuk mewujudkan suasana belajar dan proses pembelajaran agar peserta didik secara aktif mengembangkan potensi dirinya untuk memiliki kekuatan spiritual keagamaan, pengendalian diri, kepribadian, kecerdasan, akhlak mulia, serta keterampilan yang diperlukan dirinya, masyarakat, bangsa dan negara. Jalur pendidikan adalah salah satu alternatif yang dianggap cukup mampu mengatasi masalah tersebut. Pendidikan sebagai wahana preventif karena malalui pendidikan akan dibentuk generasi baru yang lebih baik. Menyikapi pentingnya pendidikan karakter, maka sangat diperlukan pendidikan karakter di Kampus untuk mewujudkan peradaban bangsa dengan memberikan keteladanan dan pembiasaan.

Bangsa Indonesia sebagai bangsa yang besar dan berbudaya, di era globalisasi saat ini banyak mengalami kemerosotan moral akibat arus globalisasi yang semakin bebas. Hal yang sangat disayangkan efek negatif dari globalisasi berdampak pada sektor pendidikan. Dunia pendidikan saat ini mengalami problem terkait krisis moral yang terjadi dikalangan peserta didik maupun tenaga pengajar. Tentunya hal tersebut sangat meresahkan masyarakat yang banyak berharap pembentukan karakter didalam dunia pendidikan. Krisis yang paling sering bermunculan adalah krisis moral/tingkah laku atau lebih dikenal dengan krisis karakter. Jika dilihat dari sudut global, munculnya banyak masalah yang dialami oleh bangsa Indonesia adalah akibat rendahnya moral dan karakter para pelaku kebijakan yang juga diikuti oleh rendahnya etos kerja masyarakat. Sederhananya solusi yang tepat adalah menerapkan pendidikan yang berlandaskan karakter (Setiawan, 2014).

Suatu karakter berkaitan dengan (watak; tabiat) dapat dipahami sebagai sikap, tingkah laku dan perbuatan baik atau buruk yang berhubungan dengan norma sosial. Oleh karena itu, erat kaitan antara karakter dan interaksi sosial. Pendidikan karakter dapat dipengaruhi banyak oleh banyak hal. Diantaranya keluarga, teman, lingkungan, dan bahasa, dan banyak lagi lainnya. Salah satu diantaranya yang paling berpengaruh adalah bahasa. Dalam berkomunikasi bahasa merupakan suatu keharusan dan modal yang mampu menunjukkan identitas diri. Baik dari situasi formal maupun non formal. Bahkan bahasa yang dianggap sebagai budaya berpengaruh besar terhadap pembentukan karakter. Seseorang mulai mengenal bahasa sejak di lingkungan keluarga, kemudian berlanjut ke lingkungan Kampus, dan masyarakat. Ini semua yang disebut lingkungan pendidikan. Namun pendidikan yang ada di lingkungan kita belum mampu memberikan nilai lebih sehingga mampu membuat seseorang menjadi mudah menghadapi masa depannya dengan baik (Sulistiyowati, 2013). 
Penelitian relevan dengan kajian penelitian ini, yaitu 1) Menurut Harahap, 2019, dengan judul Character Building Pendidikan Karakter, yang diterbitkan dalam jurnal AlIrsyad: Jurnal Pendidikan dan Konseling, Vol. 9, No. 1 (2019). Hasil dari penelitian relevan tersebut, yaitu sebagai lembaga pendidikan yang menjadi salah satu sarana pengembangan pendidikan karakter bagi siswa di sekolah. Penanaman nilai moral, etika, sopan santun dan sebagainya berlangsung dalam proses pembelajaran, pendekatan implementasi pendidikan karakter, proses pendidikan yang aktif dan menyenangkan. 2) Menurut Maunah (2015) yang berjudul Implementasi Pendidikan Karakter Dalam Pembentukan Kepribadian Holistik Siswa, yang diterbitkan dalam jurnal Pendidikan Karakter, Tahun V, No. 1 (2015), bahwa pendidikan akan secara efektif mengembangkan karakter siswa ketika nilai-nilai dasar etika dijadikan sebagai basis pendidikan yang menggunakan pendekatan yang tajam, proaktif dan efektif dalam membangun dan mengembangkan karakter siswa

Untuk mewujudkan idealitas tersebut perlu dibangun kekuatan pribadi-pribadi yang menjadi cikal bakal keluarga dan masyarakat. Mengingat pembangunan bangsa memerlukan individu dalam keluarga dan masyarakat yang saleh, yang layak memikul amanah yang dibebankan kepadanya, maka pembangunan pribadi menjadi sesuatu yang niscaya. Maka untuk mencapai harapan tersebut perlu adanya upaya serius dan bertanggungjawab karena ia adalah alat masyarakat yang terpenting dalam melaksanakan tugas sosial demi kepentingan dan tujuan bersama, memperkuat peradaban insani dan menegakkan nilai-nilai kebenaran. Kesalehan pribadi lahir dari ketakwaan yang bersifat individual sedangkan kesalehan masyarakat lahir dari ketakwaan yang bersifat kolektif. Mereka secara bersama-sama memiliki kesadaran sejarah, kesadaran tentang fakta sosial dan kesadaran tentang keharusan melakukan perubahan sebagai perwujudan kewajibannya sebagai makhluk moral dalam melaksanakan misi otentiknya, yaitu membangun peradaban (Jalil, 2012).

STKIP PGRI Lubuklinggau adalah kampus pendidikan yang ada di kota Lubuklinggau. Sebagai kampus pendidikan, STKIP PGRI Lubuklinggau tetap harus mengedepankan pendidikan moral atau karakter pada mahasiswa. Sebagai kampus yang mencetak calon guru, tentunya pendidikan karakter merupakan hal yang wajib diterapkan dalam setiap lulusannya nanti. Setiap tenaga pendidik, Dosen harus mengarahkan mahasiswa dalam pengembangan karakter yang lebih baik. Dalam mata kuliah Pancasila yang berkaitan dengan norma-norma kehidupan dalam masyarakat, sudah seharusnya mahasiswa mampu mengambil nilai-nilai karakter dalam mata kuliah Pancasila tersebut. Sebenarnya pendidikan karakter telah ada dalam diri setiap manusia, namun seiring perkembangan zaman, pendidikan karakter memang harus dijaga. Globalisasi banyak memberikan efek negatif dan mempengaruhi perkembangan karakter anak, khususnya mahasiswa. Hal-hal yang tersirat dalam mata kuliah Pancasila harus diresapi dan diamalkan dalam kehidupan sehari-hari.

Berdasarkan hasil pengamatan dilapangan, peneliti berusaha untuk menerapkan pendidikan karakter pada mata kuliah Pancasila kepada mahasiswa yang mengikuti perkuliahan. Pendidikan karakter di era globalisasi, bukan hanya terkait nilai-nilai sopan santun dan budi pekerti, namun juga berkaitan dengan bagaimana mahasiswa memanfaatkan teknologi berdasarkan kebutuhan yang mendasar. Dosen mata kuliah Pancasila harus mampu mendesain materi perkuliahan dengan baik dan mampu menggugah semangat mahasiswa untuk mengembangkan diri. Tentunya pengembangan pendidikan karakter bukan hanya diterapkan pada mata kuliah Pancasila, namun juga seharusnya diterapkan pada mata kuliah lainnya. Mahasiswa sebagai makhluk sosial harus 
pandai-pandai bergaul dan jangan sampai jatuh pada hal-hal yang negatif. Mahasiswa adalah calon penerus bangsa yang akan membawa bangsa Indonesia lebih baik dimasa yang akan datang. Menjadi manusia yang baik berbudi luhur adalah kebanggaan dan harapan bagi keluarga dan bangsa Indonesia.

\section{B. Metode}

Dalam penulisan artikel ilmiah ini, peneliti menggunakan metode penelitian deskripsi kualitatif. Penentuan subjek penelitian dilakukan dengan cara purposive yang disesuaikan dengan tujuan penelitian (Sugiyono, 2013). Pengumpulan data dalam penelitian dilakukan dengan teknik pengamatan secara langsung, observasi, dan juga berdasarkan studi dokumen yang mendukung penelitian. Peneliti merupakan instrumen utama penelitian. Peneliti sekaligus sebagai perencana yang menetapkan fokus penelitian, memilih informan, sebagai pelaksana pengumpulan data, menafsirkan data, menarik kesimpulan sementara, dan menganalisis data di lapangan yang alami (Djaelani, 2013).

Dasar teori yang menjadi landasan dalam penelitian pendidikan karakter pada mata kuliah Pancasila STKIP PGRI Lubuklinggau, adalah teori yang diungkapkan dalam sumber bukunya Sugiyono. Metode penelitian kualitatif yang digunakan sebagai landasan dalam penelitian ini dengan menggunakan alat ukur berupa pengamatan langsung yang terdapat teori Sugiyono. Dimana peneliti merupakan Dosen STKIP PGRI Lubuklinggau yang mengampu mata kuliah Pancasila, sehingga proses pengamatan dapat dilakukan secara langsung. Selain itu, untuk menunjang metode penelitian ini, peneliti menggunakan sumber referensi berupa jurnal dan buku ilmiah. Menurut (Prastowo, 2018), Kajian pustaka merupakan salah satu metode yang ada penelitian. Kajian pustaka diambil dari kajiankajian literature yang berkaitan dengan masalah yang dikaji . Teori yang mendasari masalah yang akan diteliti dapat ditemukan dengan melakukan studi kepustakaan.

Peneliti dapat memperoleh informasi tentang penelitian yang ada kaitannya dengan masalah yang dikaji. Kegiatan penyusunan kajian pustaka mempunyai tujuan untuk mengumpulkan informasi tentang kajian ilmiah, berupa teori-teori, metode, atau pendekatan yang pernah berkembang dan telah di dokumentasikan dalam bentuk buku, jurnal, naskah, catatan, rekaman sejarah, dokumen-dokumen yang terdapat di perpustakaan. Kajian literature pada penelitian ini menggunakan literature yang berkaitan dengan karakter dan literature yang berkaitan dengan karakteristik mahasiswa kampus dasar. Tinjauan literature ini berperan untuk meningkatkan nilai-nilai karakter dapat dijadikan untuk mengembangkan karakter yang ada dalam diri mahasiswa.

\section{Hasil dan Pembahasan}

\section{Karakter dan Kearifan Lokal}

Kearifan lokal atau "local genius" merupakan istilah yang diperkenalkan oleh Wales dalam Ayatrohaedi yaitu "the sum of the cultural characteristics which the vast majority of a people have in common as a result of their experiences in early life". Tesaurus Indonesia menempatkan kata kearifan sejajar dengan kebajikan, kebijakan, kebijaksanaan dan kecendekiaan. Sedang kata arif memiliki kesetaraan makna dengan: akil, bajik, bakir, bestari, bijak, bijaksana, cendekia, cerdas, cerdik, cergas, mahardika, pandai, pintar, dan terpelajar. Kearifan lokal dalam bahasa asing sering dikonsepsikan sebagai kebijakan setempat (local wisdom), pengetahuan setempat (local knowledge) atau kecerdasan setempat (local genious). Kearifan lokal sebagai kebenaran yang mentradisi atau ajeg merupakan perpaduan nilai-nilai suci 
firman Tuhan dan nilai turuntemurun yang dikembangkan komunitas tertentu. Sternberg dalam Shavinina dan Ferrari, seseorang dinilai arif apabila dapat mengakumulasi dan mengkolaborasikan antara konteks dan nilai-nilai yang melingkupinya, serta dapat mewujudkan pola hidup yang seimbang, tidak mungkin seseorang dipandang bijak apabila sikap dan tindakannya berlawanan dengan nilai yang berlaku (Daniah, 2016).

Kearifan lokal adalah segala bentuk kegiatan yang berkaitan dengan kebijaksanaan yang didasari oleh nilai-nilai kebaikan yang dipercaya, diterapkan dan senantiasa dijaga keberlangsungannya dalam kurun waktu yang cukup lama (secara turun temurun) oleh sekelompok orang dalam lingkungan atau wilayah tertentu yang menjadi domisili mereka. Kearifan lokal memiliki hubungan yang sangat erat dengan kebudayaan tradisional pada suatu tempat, dan dalam kearifan lokal tersebut banyak mengandung unsur pandangan maupun aturan agar masyarakat dapat lebih memiliki pijakan dalam menentukan suatu tindakan seperti perilaku masyarakat dalam kehidupan sehari-hari. Pada umumnya etika dan nilai moral yang terkandung dalam kehidupan secara turun temurun, diwariskan dari generasi ke generasi melalui sastra lisan dan manuskrip. Kearifan lokal yang diajarkan secara turun temurun tersebut merupakan kebudayaan yang patut dijaga yang masingmasing wilayah memiliki kebudayaan sebagai ciri khasnya dan terdapat kearifan lokal yang terkandung didalamnya (Rachmadyanti, 2017).

Karakter bangsa dibangun dari nilai etika inti (core ethical values) yang bersumber dari nilai-nilai agama, falsafah Negara dan budaya. Nilai yang bersumber dari budaya bangsa amat banyak dan beragam serta mengandung nilai luhur bangsa yang dapat menjadikan bangsa ini memiliki modal sosial yang tangguh untuk membangun peradaban unggul. Namun realitas hari ini menunjukan bahwa nilai-nilai luhur budaya bangsa, mengalami banyak tantangan, disebabkan derasnya nilai-nilai luar yang masuk dan mengintervensi nilai-nilai asli budaya bangsa. Kearifan lokal yang terdapat pada beberapa kelompok/masyarakat adat di Indonesia banyak mengandung nilai luhur budaya bangsa yang masih kuat menjadi identitas karakter warga masyarakatnya. Namun disisi lain, nilai kearifan lokal sering kali diabaikan, karena dianggap tidak sesuai dengan perkembangan zamannya. Padahal dari kearifan lokal tersebut dapat di promosikan nilai-nilai luhur yang bisa dijadikan model dalam pengembangan budaya bangsa Indonesia (Priyatna, 2016).

Wilayah nusantara yang terdiri dari ratusan suku bangsa, memiliki kearifan lokal masing-masing yang syarat dengan nilai-nilai kerukunan dalam keberagaman. Akan tetapi ketidak mampuan sekelompok masyarakat dalam menyikapi kehidupan yang multikultur telah mengenyampingkan nilai-nilai kearifan lokal yang ada. Akibatnya adalah terjadinya konflik sosial baik secara vertikal maupun horizontal. Oleh sebab itu, diperlukan upaya strategis untuk membangun kembali nilai-nilai kearifan lokal masyarakat, diantaranya melalui pendidikan. Hal tersebut dikarenakan Keberagaman dalam konteks multikultural harus dipahami sebagai diferensiasi sosial secara horizontal. Artinya, semua budaya memiliki nilai luhur masing-masing dalam tata laksananya. Dengan demikian, perbedaan dalam keberagaman tersebut tidak membicarakan eksistensi budaya satu daerah terhadap daerah yang lain. Karena kebudayaan masing-masing daerah pada dasarnya adalah komposisi dari kebudayaan nasional Indonesia yang dijamin pemerintah keberadaannya.

Seperti yang tertuang dalam Pasal 32 UUD 1945 bahwa "Negara memajukan kebudayaan nasional Indonesia di tengah peradaban dunia". Oleh sebab itu, integrasi nilainilai kearifan lokal dalam menguatkan integrasi nasional menjadi langkah strategis yang diharapkan mampu mengantisipasi setiap tindakan intoleran dalam kehidupan sosial. Gerenasi pendidik harus mampu membawa bangsa Indonesia untuk tetap memiliki 
kearifan lokal yang baik dan tetap berpegang teguh pada nilai-nilai bangsa. Berdasarkan uraian tersebut, maka diperlukan kajian mendalam mengenai integrasi nilai-nilai kearifan lokal untuk menguatkan integrasi nasional melalui pendidikan multicultural (Chotimah, Umi, 2018).

Dalam kajian penelitian (Syamsuddin Amin, 2017), yang mengkaji tentang hubungan masyarakat melalui komunikasi dalam kehidupan sosial. Pendidikan karakter yang ada di Indonesia saat ini sedang mengalami degredasi atau kemunduran moral. Hal tersebut karena kurangnya komunikasi antara generasi tua dan muda, serta dukungan berbagai pihak. Orang tua banyak sibuk dengan pekerjaannya dan menyerahkan sepenuhnya kepada dunia pendidikan untuk perkembangan anak. Moral yang kurang baik akibat pergaulan generasi muda tersebut akan dapat merusak masa depan generasi muda jika tetap dibiarkan begitu saja. Ketidak seimbangan antara perilaku, komunikasi dan norma sosial yang menyebabkan ketegangan-ketegangan sosial dimasyarakat yang menyebabkan terjadinya sebuah konflik sosial. Hal-hal terkait konflik yang muncul antar generasi muda yang mudah emosi, sangat membutuhkan perhatian dalam pembentukan pendidikan karakter. Pemuda adalah calon penerus bangsa dimasa yang akan datang. Ditangan pemuda, Indonesia akan mengalami kejayaan nantinya.

\section{Pendidikan Karakter Pada Mata Kuliah Pancasila di STKIP PGRI Lubuklinggau}

Menurut Aqib dan Sujak dalam (Prastowo, 2018), Berdasarkan grand design yang dikembangkan Kemendiknas pada tahun 2010, secara psikologis dan sosial kultural pembentukan karakter dalam diri individu merupakan fungsi dari seluruh potensi individu manusia (kognitif, afektif, konatif, dan psikomtorik) dalam konteks interaksi sosial kultural (dalam keluarga, Kampus, dan masyarakat) dan berlangsung sepanjang hayat. Konfigurasi karakter dalam konteks totalitas proses psikologis dan sosial kultural tersebut dapat dikelompokkan dalam olah hati (spiritualand emotional development), olah pikir (intellectual development), olah raga dan kinestetik (physical and kinestetic development), dan olah rasa dan karsa (affective and creativity development). Langkah pendidikan karakter di lingkungan kampus meliputi perancangan, implementasi, evaluasi dan tindak lanjut.

Sementara itu, dalam implementasi pendidikan karakter tersebut dilaksanakan dalam tiga kelompok kegiatan, yaitu: pertama, pembentukan karakter yang terpadu dengan pembelajaran pada mata kuliah yang diampu oleh Dosen. Dalam desainnya, hal tersebut dimulai dengan pengenalan nilai secara kognitif, penghayatan nilai secara afektif, akhirnya ke pengamalan nilai secara nyata oleh peserta didik dalam kehidupan sehari-hari. Kedua, pembentukan karakter yang terpadu dengan manajemen Kampus atau Universitas. Dalam desainnya, berbagai hal yang terkait dengan karakter dirancang dan diimplementasikan dalam aktivitas manajemen Kampus. Ketiga, pembentukan karakter yang terpadu dengan kegiatan kemahasiswaan lainya. Beberapa kegiatan kemahasiswaan lainnya yang memuat pembentukan kaakter antara lain: Badan Eksekutif Mahasiswa (BEM), Komunitas Kampus, olahraga, keagamaan, seni budaya, kelompok ilmiah remaja, kepramukaan, Mapala Kampus kepemimpinan mahasiswa, palang merah remaja, dan lain sebagainya.

Pendidikan karakter ini tidak hanya diperoleh dari lingkungan keluarga saja melainkan Kampus juga berhak dalam melaksanakan pendidikan karakter bagi mahasiswanya. Dengan adanya pendidikan karakter di Kampus maka akan dapat membantu pembentukkan kepribadian yang baik dalam diri mahasiswa. Pendidikan di Kampus sangat diperlukan, walaupun dasar dari pendidikan karakter adalah di dalam 
keluarga. Kalau seorang anak mendapatkan pendidikan karakter yang baik dari keluarganya, anak tersebut akan berkarakter baik pada tahap selanjutnya.

Pendidikan karakter sangat penting diterapkan. Hal ini sesuai dengan pendapat Lickona bahwa adactujuh alasan mengapa pendidikan karakter itu harus disampaikan yaitu : (1) Cara terbaik untuk menjamin mahasiswa memiliki kepribadian yang baik dalam kehidupannya. (2) Cara untuk meningkatkan prestasi akademik. (3) Sebagian mahasiswa tidak dapat membentuk karakter yang kuat bagi dirinya sendiri di tempat lain. (4) Mempersiapkan mahasiswa untuk menghormati pihak lain atau orang lain dan dapat hidup dalam masyarakat yang beragam. (5) Berangkat dari akar masalah yang berkaitan dengan masalah moral-sosial, seperti ketidaksopanan, ketidakjujuran, kekerasan, pelanggaran kegiatan seksual, dan etos kerja (belajar) yang rendah. (6) Sebagai persiapan terbaik untuk menyongsong perilaku di tempat kerja. (7) Mengajarkan akan nilai-nilai budaya merupakan bagian dari kerja peradaban (Utami, 2019).

Nilai-nilai Pendidikan Budaya dan Karakter Bangsa merupakan Nilai-nilai yang dikembangkan dalam pendidikan budaya dan karakter bangsa dan diidentifikasi dari sumbersumber Agama, karena masyarakat Indonesia adalah masyarakat beragama, maka kehidupan individu, masyarakat, dan bangsa selalu didasari pada ajaran agama dan kepercayaan. Secara politis, kehidupan kenegaraan didasari pada nilai yang berasal dari agama. Sumber yang kedua adalah Pancasila, Pancasila : Negara kesatuan Republik Indonesia ditegakkan atas prinsipprinsip kehidupan kebangsaan dan kenegaraan yang disebut dengan Pancasila. Pancasila terdapat pada Pembukaan UUD 1945 dan dijabarkan lebih lanjut lagi dalam pasal-pasal yang terdapat dalam UUD 1945.Artinya, nilai-nilai yang terkandung dalam Pancasila menjadi nilai-nilai yang mengatur kehidupan politik, hukum, ekonomi, kemasyarakatan, budaya dan seni (Omeri, 2015).

Pendidikan karakter dalam pembentukan akhlak mulai dapat dilakukan dengan cara terintegrasi dengan mata kuliah yang diajarkan di lingkungan kampus. Di lingkungan kampus yang telah menggunakan kurikulum yang terupdate dengan terintegrasi dengan mata kuliah yang diampu oleh Dosen dengan pembelajaran akhlak. Sebelum pembelajaran dimulai terlebih dahulu diadakan kegiatan leterasi dan setelah pembelajaran diadakan kegiatan kemahasiswaan untuk membentuk akhlakul karimah. Pendidikan karakter dalam pembentukan akhlakul karimah memiliki peran strategis, yaitu untuk membentengi peserta didik dari pengaruh arus globalisasi kompetensi, keterampilan yang ungul agar mampu mengikuti persaingan global. Pendidikan karakter yang baik adalah pendidikan dengan mengintegrasikan mata kuliah dengan akhlukul karimah yang didasarkan pada ajaran agama dan dilakukan dengan rasa kasih sayang, kesabaran, keteladanan, serta nasihatnasihat yang bijaksana dan memungkinkan diimplementasikan dalam kehidupan seharihari (Badawi, 2019).

Dalam pelaksanaan pendidikan karakter di Kampus, dengan menerapkan kebiasaan pada mahasiswa untuk berperilaku baik perlu ditunjang oleh keteladanan Dosen dan lingkungan kampus serta semua elemen dalam Kampus tempat mahasiswa menimba ilmu pengetahuan dan cita-cita. Di Kampus tersebut, semua elemen harus memberikan contoh yang layak untuk ditiru, karena elemen kampus yang baik akan menciptakan lulusan yang baik juga. Mata kuliah Pancasila yang diajarkan oleh Dosen, harus mampu mendesain materi agar memberikan efek pada pembentukan karakter selain memberikan ilmu pengetahuan bagi mahasiswa. Tentunya Pancasila yang diajarkan di kampus, akan mampu untuk diaplikasikan pada kehidupan sosial mahasiswa STKIP PGRI Lubuklinggau. 
Pendidikan karakter (character building) menjadi hal sangat penting dan menjadi perhatian khusus bagi lembaga pendidikan. Pendidikan karakter merupakan penanaman nilai-nilai moral kepada seseorang atau sekelompok orang dan mendorong mereka untuk melakukan kebiasaan-kebiasaan baik dalam kehidupan sehari-hari seperti sopan santun, etika berbicara, sikap jujur, bertanggung jawab, adil, religius, dan sebagainya. Lembaga pendidikan menjadi salah satu sarana pengembangan pendidikan karakter bagi mahasiswa di kampus. Penanaman nilai moral, etika, sopan santun dan sebagainya berlangsung dalam proses pembelajaran, pendekatan implementasi pendidikan karakter, proses pendidikan yang aktif dan menyenangkan (Harahap, 2019). Pentingnya pendidikan karakter bagi mahasiswa merupakan suatu keperluan yang tidak terbantahkan lagi. Namun demikian, tujuan pendidikan karakter tetap sama, yakni mengantarkan mahasiswa mempunyai kepribadian dan nilai-nilai karakter mulia, seperti religius, jujur, toleransi, disiplin, kerja keras, kreatif, mandiri, demokratis, rasa ingin tahu, semangat kebangsaan, cinta tanah air, menghargai prestasi, bersahabat atau komunikatif, cinta damai, gemar membaca, peduli lingkungan, peduli sosial, dan tanggung jawab (Murniyetti, 2016).

Sebagai Dosen yang selalu mengampu mata kuliah Pancasila dari berbagai prodi di STKIP PGRI Lubuklinggau, mahasiswa sebelumnya hanya fokus dalam mengikuti perkuliahan dengan orientasi mendapatkan nilai yang bagus di akhir semester. Dosen biasanya hanya mengikuti rancangan pembelajaran semester (RPS) yang dibuat sesuai mata kuliah yang diampu. Namun seiring berjalannya waktu, Dosen lebih mendesain RPS mata kuliah Pancasila lebih mengarah dalam pembentukan karakter. Mahasiswa dalam mengikuti perkuliahan bukan hanya duduk, mendengar, diskusi kelompok dan pulang. Namun mahasiswa dituntut untuk menganalisis dan memahami lebih dalam terkait normanorma dan nilai yang terkandung didalam mata kuliah Pancasila. Mengingat mayoritas mahasiswa memiliki kegiatan lain sebagai anak organisasi, maka pengenalan pendidikan karakter didalam mata kuliah Pancasila sangat penting. Dosen pengampu mata kuliah Pancasila selalu menjelaskan materi terbaru sesuai perkembangan dunia saat ini. Jadi mahasiswa harus mampu mengaplikasikan pendidikan karakter yang ada dalam mata kuliah Pancasila dalam kehidupan kampus, berorganisasi, dan bermasyarakat.

Di dalam penanaman pendidikan karakter di lingkungan kampus STKIP PGRI Lubuklinggau, peran Dosen dan mahamahasiswa yang bersinergi dengan lingkungan kampus harus tetap terjaga. Dosen sebagai orang tua mahamahasiswa dilingkungan kampus harus bertingkah laku yang baik dan menjadi teladan bagi mahamahasiswa. Selanjutnya, keteladanan diwujudkan dengan cara bertutur kata, bersikap, memiliki sifat, dan berpenampilan yang sesuai dengan karakter religius, jujur, disiplin, demokratis, semangat kebangsaan, cinta tanah air, menghargai prestasi, cinta damai, gemar membaca, peduli lingkungan, dan peduli sosial yang dilakukan secara berkesinambungan. Oleh kerana itu, perlu dipahami dan diajarkan bahwa dengan menjadi Dosen yang berkarakter, mahamahasiswa akan merasa memiliki panutan atau model dalam mewujudkan pribadi muslim yang berkarakter dan berbudaya sesuai kearifan lokal bangsa Indonesia yang dikembangkan dilingkungan kampus STKIP PGRI Lubuklinggau. Jadi kedepan generasi muda lulusan sarjana pendidikan, selain memiliki pengetahuan yang luas, juga selalu berkarakter dalam bertindak.

\section{Kesimpulan}

Dalam penelitian sebelumnya yang dilakukan Umi Chotimah (2018), sebagai bangsa yang beranekaragam, Indonesia sudah biasa muncul sebuah perbedaan. Perbedaan tersebut 
bukan saling memisahkan, namun saling mengaitkan untuk membentuk karakter bangsa yang kuat. Semua perbedaan yang menjadi konflik harus dihindari. Kearifan lokal yang muncul bagi bangsa Indonesia sudah seharusnya dikembangkan kembali sebagai acuan dalam pendidikan karakter yang membangun bangsa Indonesia. Sedangkan menurut penelitian sebelumnya yang dilakukan oleh Priyatna (2016), yaitu pendidikan karakter bersumber dari nilai-nilai agama, falsafah Negara dan budaya. Nilai-nilai yang bersumber dari pendidikan karakter tersebut merupakan modal dalam membangun bangsa Indonesia yang unggul dan maju.

Selanjutnya berdasarkan hasil analisis sumber dari jurnal dan buku yang relevan dengan penelitian, diketahui bahwa nilai-nilai dalam pendidikan karakter yang diterapkan dalam mata kuliah sudah sangat baik. Penerapan pendidikan karakter yang dilakukan oleh Dosen juga diterapkan dalam bentuk tingkah laku yang berbudi luhur. Dosen harus bertingkah laku baik didalam dan diluar lingkungan kampus. Penerapan pendidikan karakter juga harus diterapkan dalam setiap kegiatan-kegiatan mahasiswa yang melibatkan nama lembaga kampus. Hal tersebut dilakukan agar segala kegiatan yang diadakan mahasiswa memiliki manfaat dan pengaruh yang baik bagi perkembangan kehidupan kampus dimasa kini dan masa yang akan datang. Sinergi antara mahasiswa dan Dosen dalam mendukung pendidikan karakter itu sangat penting. Karakter harus dibangun sejak dini, dan dikembangkan saat berada dilingkungan masyarakat yang luas.

Selanjutnya, kedepan diharapkan penelitian ilmiah yang lebih baik terkait pendidikan karakter di lingkungan kampus STKIP PGRI Lubuklinggau lebih diperluas lagi. Pembahasan pendidikan karakter lebih ditekankan pada pengembangan bahan ajar dan media yang disesuaikan dengan kurikulum dan perkembangan zaman. Hal tersebut agar mahasiswa atau siswa di sekolah mampu menyerap pendidikan karakter lebih luas. Sesuai perkembangan zaman saat ini peran media dalam menyampaikan sebuah materi lebih fleksibel dan terkesan menyenangkan bagi peserta didik. Adanya pengembangan media tersebut, peserta didik akan menjadi lebih bersemangat dalam belajar. Peserta didik mampu mengakses media tersebut untuk dipelajari kapan dan dimanapun mereka berada. Selain itu, jangkauan penelitian pengembangan yang diharapkan akan lebih luas bukan hanya kalangan mahasiswa, namun juga siswa sekolah.

\section{Daftar Pustaka}

Badawi. (2019). Pendidikan Karakter Dalam Pembentukan Akhlak Mulia di Sekolah. SEMINAR NASIONAL PENDIDIKAN, 207-218. Retrieved from https://jurnal.umj.ac.id/index.php/SEMNASFIP/index

Chotimah, U.D. (2018). Pengintegrasian Nilai-Nilai Kearifan Lokal Dalam Pendidikan Multikultural. Jurnal Civics: Media Kajian Kewarganegaraan, 15(1), 19-25.

Daniah. (2016). Kearifan Lokal (Local Wisdom) Sebagai Basis Pendidikan Karakter. PIONIR: Jurnal Pendidikan, 5(2), 1-14.

Djaelani, A. R. (2013). “Teknik Pengumpulan DatadalamPenelitian Kualitatif." Majalah Ilmiah Pawiyatan, XX(1), 82-92.

Harahap, A. C. P. (2019). Character Building Pendidikan Karakter. Al-Irsyad: Jurnal 
Pendidikan Dan Konseling, 9(1), 1-11.

Jalil, A. (2012). Karakter Pendidikan untuk Membentuk Pendidikan Karakter. Nadwa Jurnal Pendidikan Islam, 6(2), 175-192.

Kemdiknas. (2003). Undang-Undang RI Nomor 20 Tahun 2003. Jakarta: Kementerian Pendidikan Nasional.

Murniyetti, D. (2016). Pola Pelaksanaan Pendidikan Karakter Terhadap Siswa Sekolah Dasar. Jurnal Pendidikan Karakter, VI(2), 156-166.

Omeri, N. (2015). Pentingnya Pendidikan Karakter Dalam Dunia Pendidikan. Manajer Pendidikan, 9(3), 464-468.

Prastowo, A. (2018). Pendidikan Karakter di Sekolah Dasar/Madrasah Ibtidaiyah Berbasis Pemberdayaan Pikiran Bawah Sadar. Al-Aulad: Journal of Islamic Primary Education, $1(2), 54-64$.

Priyatna, M. (2016). Pendidikan Karakter Berbasis Kearifan Lokal. Jurnal Edukasi Islami Jurnal Pendidikan Islam, 5(10), 1311-1336.

Rachmadyanti, P. (2017). Penguatan Pendidikan Karakter Bagi Siswa Sekolah Dasar Melalui Kearifan Lokal. JPSD, 3(2), 201-214.

Setiawan, A. (2014). Prinsip Pendidikan Karakter Dalam Islam (Studi Komparasi Pemikiran Al-Ghazali dan Burhanuddin Al-Zarnuji). Dinamika Ilmu, 14(1), 1-12.

Sugiyono. (2013). Memahami Penelitian Kualitatif. Bandung: Alfabeta.

Sulistiyowati, E. (2013). Pendidikan Karakter Dalam Pembelajaran Bahasa Indonesia. Edukasia: Jurnal Penelitian Pendidikan Islam, 8(2), 311-330.

Syamsuddin, M. A. (2017). Komunikasi Sebagai Penyebab dan Solusi Konflik Sosial. Jurnal Common, 1(2), 101-108.

Utami, S. W. (2019). Penerapan Pendidikan Karakter Melalui Kegiatan Kedisiplinan Siswa. Jurnal Pendidikan, 4(1), 63-66. 